\title{
ESCAPING THE “VIRTUAL PROMENADE” - NEW TRENDS IN USE OF SOCIAL NETWORKS BY MEMBERS OF GENERATION “Z”
}

\author{
Tomislav Levak, Snježana Barić Šelmić \\ Department of Cultural Studies, University of Josip Juraj Strossmayer in Osijek, Osijek, Croatia
}

\begin{abstract}
The aim of this paper is to determine whether the younger population in Croatia is following the dominant world trends in the use of social networks as extremely widespread communication platforms. Namely, although the Facebook community currently consists of as many as two billion users and is still convincingly the most popular social network in the world, it has already been noted that members of the so-called generation Z (people born after 1995) across the world are increasingly abandoning or minorizing Facebook and turning to other social networks.

To this end, the authors used the comparative method to investigate the use of several contemporary social networks and current trends in the world and Croatia, using the necessary theoretical framework. Also, during May of 2017, the authors conducted a research into online habits and attitudes on social networks which has not yet been done in Croatia, in the authors' knowledge - by means of an online survey among secondary school students, members of generation Z, in several major and smaller Croatian cities: Zagreb, Osijek, Krk and Korčula.

The results of the research confirmed the initial hypotheses of the authors: young people are increasingly leaving Facebook as a "virtual promenade", largely because older generations began using it, including their parents; they are mostly turning to social networks that offer a prevalence of photographs over text, primarily Instagram and Snapchat. In addition, no significant differences were found between members of generation $\mathrm{Z}$ in larger urban areas on the continent and smaller urban areas on the Adriatic islands, when it comes to their preferences.
\end{abstract}

\section{Keywords}

social networks, generation Z, communication platforms, Facebook, Instagram, Snapchat

\section{Introduction}

Over the past few years, in the world, as well as in Croatia, there has been a growing increase in the number and the emergence of different kinds of social networks that are rapidly becoming trends among users. This is especially true of members of the younger generation, who are constantly looking for new virtual challenges and different communication and media platforms to share their desired content.

This is evidenced by the results of recent research at the time of writing this paper. According to the official latest data from DreamGrow, a relevant web site that is continually studying the phenomena of social networks and content marketing $/ \mathbf{1} /$, the number of users of different social networks in the world is constantly increasing. In
July 2017, the first place among the 15 most popular social networking sites (SNSs) was still convincingly held by Facebook, with the number of its regular users over the age of 13 - the lower age limit for opening a Facebook profile /2/ - recently reaching a full two billion. When it comes to social networking apps, Messenger and WhatsApp were the most represented, each with approximately 1.2 billion users worldwide /3/, and increasingly used by Croatian citizens.

As far as Croatia is concerned, a series of publicly available data, such as those from the January 2016 global research labeled Digital in 2016 by the US marketing agency We Are Social, indicate that Croatian citizens have been strongly affected by the trend of massive active use of social networks. Namely, there were around 3.1 
million Internet users in Croatia, whose population is around 4.2 million people, 1.8 million of which are active social network users and 1.5 million active social network users via a "smart" phone /4/. These figures are now almost certainly higher. This is confirmed by an analysis of the specialized digital agency Arbona, conducted in December 2016, where only the most popular network, Facebook, had 1.9 million permanent active users in Croatia, out of which approximately 570 thousand in the younger age cohorts (13 to 24 years old), while data was not published for other social networks $/ 5 /$.

On the other hand, a few years ago, the results of several global research studies, including one carried out by the Marketo Agency in the United States in 2014, showed that more and more members of the so-called generation $\mathrm{Z}$ - then at the age of 13 to 17 - are leaving Facebook because they find other, more modern and faster social networks such as Whisper, Secret, Snapchat and Instagram, much more appealing. The biggest reason is that they find Facebook to be, as a rule, insufficiently interesting. Such an attitude is not surprising, especially since the attention span of members of the generation averages only eight seconds $/ 6 /$.

All the above-mentioned facts, as well as the lack of similar research in Croatia, have led the authors to work on this topic in order to determine whether the younger population in Croatia is in line with world trends regarding the use and preference of certain social networks, as extremely widespread communication platforms. In this context, the authors provide the necessary basic theoretical framework, noting that professional literature on this relatively new topic is still incomplete, leading them to partly rely on internet and other sources. In the practical part, the paper uses the comparative method and the empirical research on internet habits and attitudes regarding social networks was conducted using an online survey among targeted members of generation $\mathrm{Z}$ in four selected Croatian cities, the results of which are presented in the final part of the paper.

\section{Social networks in the context of new media and globalization}

Social networks, as defined by Plavljanić, are websites where one can create a profile, edit it, communicate with acquaintances (and strangers), share content, and advertise if one owns a business or marketing agency /7/. Boyd and Ellison add to this with their definition of social network sites (SNSs), "as web-based services that allow individuals to (1) construct a public or semipublic profile within a bounded system, (2) articulate a list of other users with whom they share a connection, and (3) view and traverse their list of connections and those made by others within the system" /8/. Although social network existed earlier in various versions, most authors - including Plavljanić, Boyd and Ellison - agree that SixDegrees.com is the first Internet site in history that could be called a typical social network. It was created in 1997 and existed for just four years. "It was based on creating profiles and lists of friends one could communicate with, but one could also connect with unknown people at the network and see their links and acquaintances" /9/, which is all similar to today's SNSs. Several years later, many members of the world population realized that "the Internet is the perfect tool for breaking all hierarchies" /10/ and that social networks are becoming more and more popular and rapidly evolving into the current global communication phenomenon /11/. According to Boyd-Barrett, "three features determine globalization: 1) its global comprehensiveness (globalization processes affect all countries), 2) it is based on the western model of transnational companies, and 3) the core infrastructure that ICT is based on" /12/, or more precisely - information and communication technology /13/. Following the trends in recent years, it is not difficult to ascertain that social networks contain all three characteristics, but they are not alone in this. A number of Croatian and foreign communications experts, such as Labaš and Riva, have noted over the past decade that "owing to technological advancements, man has transcended social communication into social communication, in which mass media are used" /14/, that is "in this communication the media has an increasingly important role today, experiencing an unstoppable development" /15/. Labaš emphasizes that "these media have joined the traditional mass media (such as press, radio and television) in the last decades of the twentieth century, and as these new means of communication have special features, they have earned the label 'new media"' /16/. Referring to Negroponte /17/, Labaš cites some of the most important features of new media: processing data in digital form, then mul- 
timedia, interactivity and hyper-textuality /18/, as well as the appearance of ever more virtual communities /19/. Some authors, such as Thurow /20/, directly count social networks into new (mass) media, while others do so indirectly. Thus, Šišak emphasizes that "in the general flourishing of Internet and other content," the main motives of those involved include: (1) to inform and be informed; (2) to have fun and enjoy oneself; (3) to create /21/. Even more detailed is McQuail, who states that "the differences of the new versus the old media, apart from the key technical one, that the form is digitized; consist of the following features: (1) new media enable communication of alltowards-all; (2) allow simultaneous reception, modification and redistribution of cultural objects; (3) dislocation of communicative activities from their place of origin and from territorial spatial relations of modernity; (4) provide instant global contact; (5) add a modern/postmodern subject to a machine that is networked" /22/. The analysis and monitoring of social networks shows that all the mentioned characteristic pertain to them as well, and with their constant development, their outspread and popularity increase as well.

\subsection{The growing popularity of social net- works}

The trend for growing popularity of social networks was for the first time, according to Tancer, more seriously detected over ten years ago. In the spring of 2007, the comparison of global numerical indicators of market share in the internet email services market (webpages such as Yahoo!Mail, Hotmail and Gmail), which have long been the most popular category of internet sites based on the market share of visits, and social networks, has shown that the number of visits to social networks for the first time exceeded the number of visits to email services. Specifically, in the observed period from 23 April 2005 to 28 April 2007, the double ratio of $8.2 \%$ vs. $4.0 \%$ of email service use compared to social network use, was overturned in just two years $-10.8 \%$ vs. $11.0 \%$. /23/. Two years later, in March 2009, as Kirkpatrick points out, an epochal change on the Internet occurred. The measurements conducted by the Nielsen Company research firm showed the following results: "Time spent on social networks by Internet users worldwide had for the first time exceeded the amount of time Internet users spent on e-mail. A new form of communica- tion had gone mainstream. Total time spent on social networks grew a healthy 63 percent in 2008 around the world" /24/.

Since then, the number of visits and types of social networks has been increasing exponentially. That is why today "social media platforms are embedded in our cultural lives and are integral to how we think about social interaction" /25/. Just how true that is, is confirmed by data on the impressive number of users of individual social networks that DreamGrow collected from multiple sources and released in July 2017. Following Facebook, the top 14 most popular social network sites (SNSs) were: YouTube (with about one billion users), Instagram (700 million), Twitter (313 million), Reddit (250 million), Vine (200 million), Ask.fm (160 million), Pinterest (150 million), Tumblr (115 million), Flickr (112 million), Google + (111 million), LinkedIn (106 million), VK (90 million), Classmates (57 million) and Meetup (30.3 million). The "top 10" social networking apps are: Messenger and WhatsApp in the lead (each with about 1.2 billion users), QQ Chat (899 million), WeChat (806 million), Instagram (700 million), QZone (652 million), Viber (249 million), LINE (218 million), Snapchat (200 million) and YY (122 million) $/ \mathbf{2 6}$. Adding to the fact that the strongest global social network is also the owner of Messenger, WhatsApp and Instagram, it is clear just how much Facebook is dominant throughout the world, including middle-aged and elderly users.

\section{Facebook}

In short, Facebook is a popular free social networking site that allows registered users to create profiles, upload photos and videos, send messages and keep in touch with friends, family and colleagues. The site, which is now available in 37 different languages, includes public features such as: marketplace, groups, events, pages and presence technology /27/. Addressing the emergence and growing number of social networking sites, Briggs and Burke in 2011 stated: "Their success has shown that many users do not use the internet in search of isolation but in search of interaction: out of a desire to create contacts in cyber space with other users. One of the most successful new companies that responded to what was labeled "community thrust" was Facebook, founded in February 2004 by Mark Zuckerberg. In 2008, it already reached 161 million members"/28/. A year before Briggs and Burke, the rapid expansion of 
Facebook was also noted by Mezrich, saying, "whatever its real value, its stunning growth is not waning" /29/.

Despite the emergence of a number of new social networks, Facebook's growth trend is still running, so the number of its users at the time this paper was written encompassed over a quarter of the total world population. Judging by the results of the iZone Agency's survey, conducted at the end of 2016 among citizens of different age groups, the situation in Croatia is similar. Facebook, as interpreted at the specialized Media Marketing website, is still "the king of social networks". Among other things, it argues that $56 \%$ of the participants in the mentioned research identified Facebook as the best social network on the internet, according to several parameters, while half of them would give up Facebook last, of all researched social networks /30/. The current state of affairs among young people in Croatia is portrayed in the results of the research conducted for this paper.

\section{Attributes of generation $\mathrm{Z}$}

As Reić points out, social sciences in the last eighty years or so differentiate between several generations of humankind, with regard to different social and historical periods /31/. Different sources may offer minor or greater disagreements about the names, scope and characteristics of individual generations, but almost all agree on the last three generations labeled with letters. These are: generation $X$ (the lost generation, whose members are generally born between 1966 and 1976), generation Y (Millennium, Millennials or Echo Boomers, born between 1977 and 1994) and generation $\mathrm{Z}$ encompassing young persons born between 1995 (or 1997, depending on the author) and 2012 /32/. Members of generation $Z$ have a number of recognizable features, but the authors here only outline those related to the use of ICT, social networks and the media in general. As a specialized Socialmarketing.org website comments: "Gen Z kids will grow up with a highly sophisticated media and computer environment and will be more Internet savvy and expert than their Gen $Y$ forerunners" /33/. Generation $Z$ is often referred to as Generation 2020, because that is roughly when most of the members of this generation will enter the labor market, while other popular names for it are the Face generation and the iPhone generation. "Generation $\mathrm{Z}$ members can boast many of the abilities and benefits of life in the modern technology era. They are blessed with the ability to multitask, or perform multiple tasks at the same time and with very effective results. They receive and process information very quickly, but at the same time require easy access to information. The life of the members of generation $\mathrm{Z}$ takes place in a world of hyper-production, networking, virtuality" /34/. Reić adds that they are young people who live in a networked world that has enabled them to communicate with the whole world with just one 'click' /35/. Such a pattern of behavior is common for generation $\mathrm{Z}$, which is why they are rightly called "digital natives".

\section{1. "Digital natives" and "digital immi- grants"}

Castells was among the first to mention the shift from traditional mass media to the system of horizontal communication networks, organized around the internet and wireless communications, which introduced the diversity of communication patterns at the source of fundamental cultural transformations and demonstrated how virtuality becomes the essential dimension of contemporary reality /36/. Creating a new culture based on multimodal communication and digital information processing, created a generational division into those born before the internet era (beginning in 1969) and those who grow up being digital. Prensky named them "digital immigrants" and "digital natives". In other words, digital natives are all "native speakers" of the digital language of computers, video games and the Internet, while digital immigrants are described as "those of us who were not born into the digital world but have, at some later point in our lives, become fascinated by and adopted many or most aspects of the new technology era" $/ 37 /$. At that, he emphasizes that as much as digital immigrants try to adapt to their environment, they always retain, to some degree, their "accent" that will forever differentiate them from the digital natives $/ 38$ /, thus creating a generational gap.

According to Castells, this modern world is a new communicational empire, whose backbone is made up of computer networks, a digital language, and transmitters that are globally distributed and globally interactive. The paradigm of information technology is not geared towards its 
conclusion but its openness /39/. This openness allows simple migrations from one social network to another, a phenomenon that has been observed in recent years especially among the younger population, and is also analyzed in the empirical part of this paper.

\section{Methodological framework and research objectives}

The main objective of this research - the likes of which has not been conducted in Croatia, to the authors' knowledge - was to determine whether the younger population in Croatia is also following world trends in the use of social networks, as ever more popular and widespread communication and media platforms. Although Facebook is globally still the most popular social network, there has been a worldwide trend in recent years, in which members of generation $\mathrm{Z}$ are increasingly abandoning or minorizing Facebook and turning to other social networks.

For this purpose, qualitative and quantitative research methods have been combined. In order to carry out a more comprehensive analysis of internet habits and attitudes of the younger populations on social networks, as well as the analysis of the comparative advantages and disadvantages of certain social media, a comparative method and online survey method were used among high school students in several major and smaller Croatian cities: Zagreb, Osijek, Krk and Korčula. The starting point was the abovementioned research of the Croatian audience's preferences in the use of social networks, conducted by the iZone agency at the end of 2016, with results published in February and March 2017 /40/. The research for the purpose of this paper was carried out in order to examine the initial hypothesis of the authors: young people are increasingly leaving Facebook as a "virtual promenade", largely because it was discovered, mastered and increasingly used by older generations, including their parents; and they are turning more and more towards social networks that predominantly offer pictures over text, primarily Instagram and Snapchat. Additionally, the authors wanted to determine when young people were likely to choose and use social networks, and whether there are differences in preferences among members of generation $\mathrm{Z}$ in larger urban areas on the continent and in smaller urban areas on the Adriatic islands.

\subsection{Comparative method}

Collier points out that the comparative method is often applied in social sciences $/ \mathbf{4 1} /$, and that it allows the identification of similarities, common features or differences between two events, phenomena or objects $/ 42 /$. In this case, the comparative method has been applied on several occasions: when comparing the characteristics of particular social networks and the characteristics of digital natives and digital immigrants, as well as in drawing parallels between the results of several different research studies important for this paper. Thus, some of the conclusions reached by the authors using the comparative method were already presented in the theoretical part of the paper, while the rest of the data is presented in the interpretation of the research results.

\subsection{Online survey method via questionnaire}

In the period between 1 and 31 May 2017, during the school year, an online survey, as the main research tool, was conducted via a written questionnaire among students of several secondary schools in four selected Croatian cities. Since there are disputes over the age range of generation $Z$, i.e. whether it includes young people born from 1995 or 1997, the authors selected the secondary school population for analysis, to make sure that the survey included only members of that generation.

The basis for the sample selection was official data, collected during the last census of the Republic of Croatia in 2011, and the latest publicly available data of the Croatian Central Bureau of Statistics before the implementation of the survey. According to them, in the 2015/16 school year, a total of 170,661 students attended secondary school, which is $4,5 \%$ less than at the beginning of the 2014/15 school year /43/. The sample consisted of 800 subjects $(\mathrm{N}=800)$ or almost $0.5 \%$ of the members of the reference group. The authors received 453 completed questionnaire replies $(\mathrm{N}=453)$, meaning that the rate of response was an above average $56.6 \%$. The sample is nationally representative of age, gender, region, population and number of secondary school students. Name$1 y$, according to the 2011 census of the population of Croatia /44/ and the research objectives, the authors decided to conduct an online survey in the following cities: Zagreb (790.017 inhabitants), Osijek (108.048 inhabitants), Krk (6.281 inhabit- 
ants) and Korčula (5.663 inhabitants). The basic criteria were size and population: Zagreb and Osijek are the largest cities in the continental part of Croatia, and Krk and Korčula are the largest Adriatic islands, with a total of 17,860 or 16,182 inhabitants respectively, of which several cities have secondary schools. In addition, the criterion of geographic distribution of the sample was also met by this choice, as the research included eastern (Osijek), western (Krk), central/northern (Zagreb) and southern (Korčula) Croatia. Based on the census of the population and secondary school system in the Republic of Croatia, 22 secondary schools were selected, among them approximately 16 in the city of Zagreb, 4 schools in Osijek and one school in Krk and Korčula each. The authors took into account the equal representation of gymnasiums, technical and vocational secondary schools in relation to their total number, as well as the coverage of an equal number of students in the $1^{\text {st }}, 2^{\text {nd }}, 3^{\text {rd }}$ and $4^{\text {th }}$ grade of secondary school, to whom an online survey questionnaire was sent randomly. The average age of respondents was almost 17 years $(M=16.74)$. Although surveys are nominally a quantitative method, which also enables a generalization of answers, the authors chose to combine quantitative and qualitative methods by including a total of 15 closed-type questions (with answers provided) and 5 open-type questions (no prior answers provided) in the questionnaire. In this way, the authors believe they would have more precise results as well as a more realistic insight into the situation among the technologically aware younger population. Driven by the content and rankings of the social network popularity chart published in January 2017 by DreamGrow /46/, SNSs and social networking apps were divided into two distinct categories. In this respect, the research included 7 out of 15 most popular SNSs: Facebook, Instagram, Twitter, Pinterest, Tumblr, Google + and LinkedIn. They have a wider reach in Europe, not just Asia or the US, and belong to classic SNSs rather than internet services like YouTube. On the other hand, the same criteria - a high position on the popularity scale, classical features and popularity in Europe were also applied to social networking apps. Therefore, WhatsApp, Messenger, Viber, and Snapchat were analyzed, along with the addition of SMS, which is somewhat outdated, but still used by the younger generation.

This approach is similar to the one used by the iZone agency in its reference study $/ 47 /$, but noting that it only dealt with a qualitative analysis. Also, the authors did not delve into the sociological and psychological components for choosing certain social networks since they were primarily interested in the dominant trends and the reasons for choosing particular social platforms presented by members of generation $\mathrm{Z}$ themselves.

\section{Interpretation of research results}

When sending online questionnaires, the authors took care to have at least an approximately equivalent gender structure of the targeted respondents to that of the general population of the Republic of Croatia. According to the 2011 census, for the analyzed age ranges from 15 to 19 there were 124.918 men (approximately 51.2\%) compared to 119.259 women (about $48.8 \%$ ) /48/. Therefore, among the 800 envisaged respondents, there were more male secondary school students. However, female secondary school students showed a higher level of conscientiousness and responsibility in completing and returning the questionnaire, so there are two thirds of young women $(64.7 \%)$ compared to $35.3 \%$ of young men among 453 responses. Given that the responses did not contain significant gender differences and deviations, the authors do not believe that this ratio diminishes the relevance of the research (see Graph 1). 
Graph 1. Distribution of participants in the online survey by gender

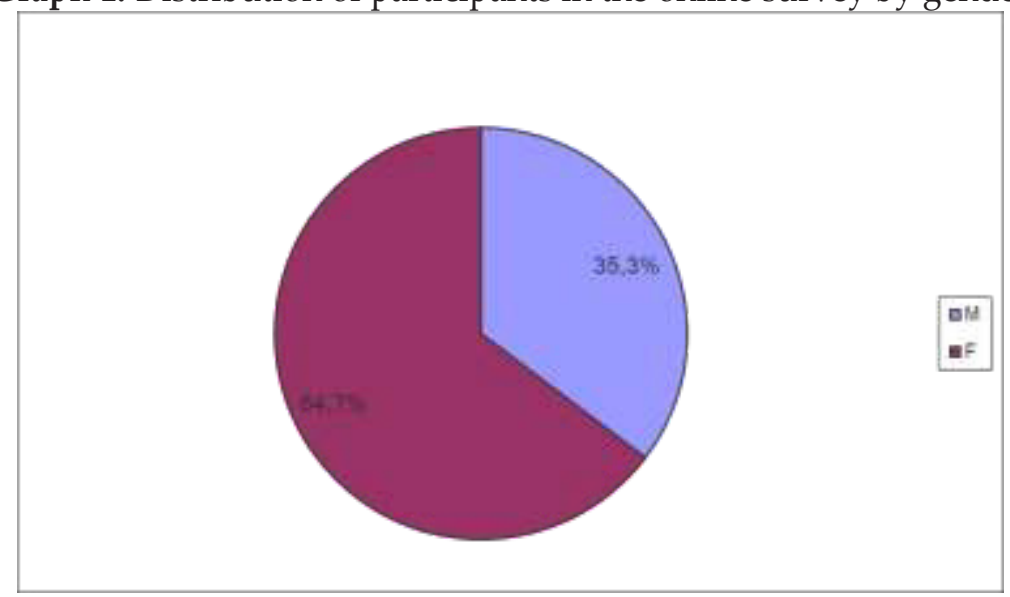

Source: Own production

As expected, when asked "How often do you use the internet?", all 453 respondents (100\%) responded that they use it several times a day (see Graph 2). So, everyday, without exception, and several times during the day. This is evidenced by the fact that the internet has become the most important and unavoidable medium for younger generations, and social networks have a big role to play in that.

Graph 2. Frequency of internet use

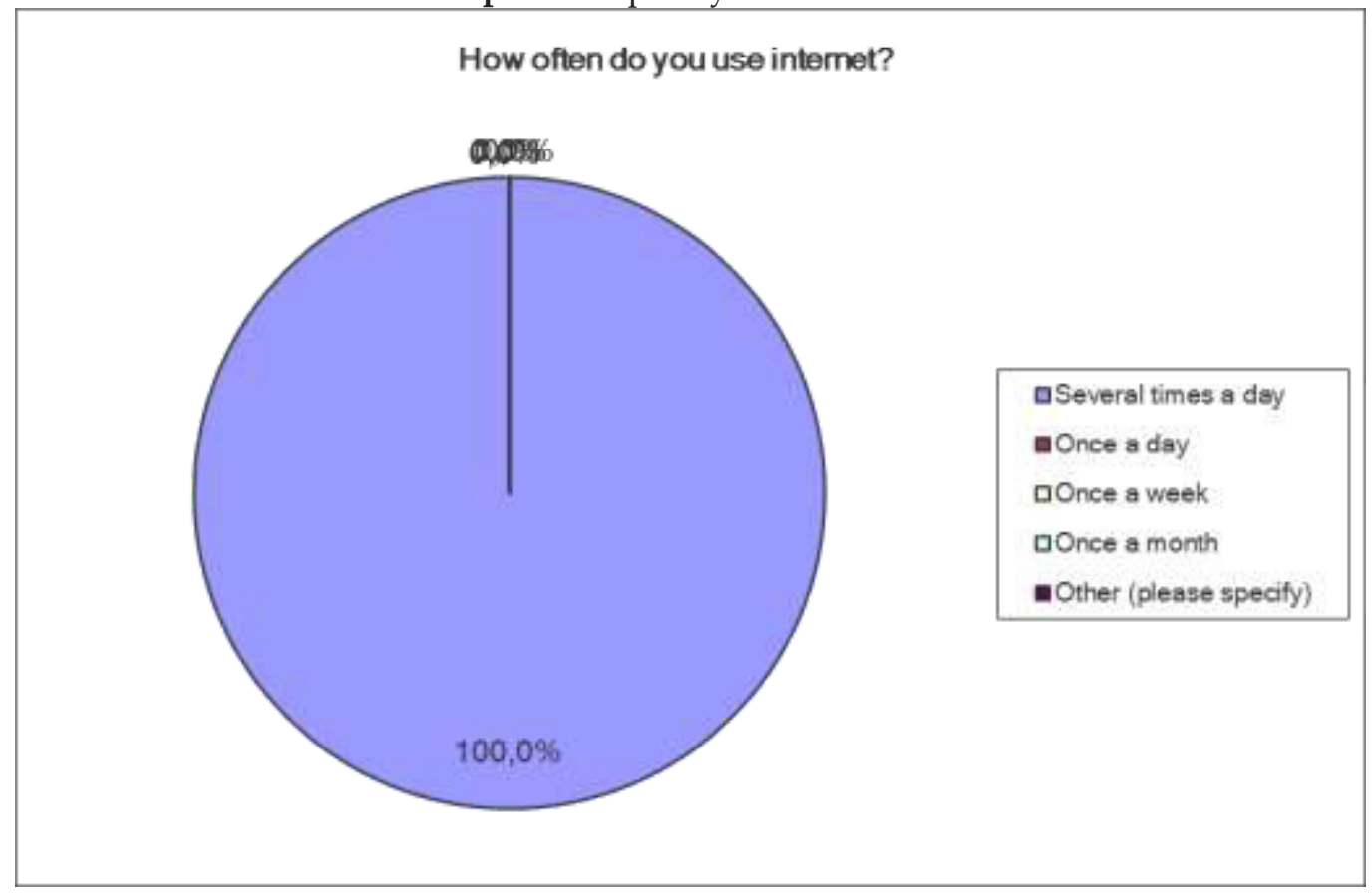

\section{Source: Own production}

In Graph 3 there is another answer that could have been assumed in advance: as many as $94.1 \%$ of surveyed adolescents access the internet via a "smart" phone, that is, use mobile internet access. Interestingly, the other $5.9 \%$ accesses the internet access via PCs, while no respondents have admitted to using any other way: laptop, tablet, iPad, smart TV or something else. But this is an indication that it is no longer important to be in a specific place because mobile internet access enabled a revolutionary complete mobility, no matter where one may be physically. Everyone interested can use the internet, listen to music, watch films, make phone calls and communicate in other ways through just one device - a "smart" phone. Steve Jobs said at the presentation of the iPhone that the idea was that everything a person needs can fit into that phone, and that they could always carry it with them $/ 49 /$, which was accomplished, and used to the great benefit of the younger population. 


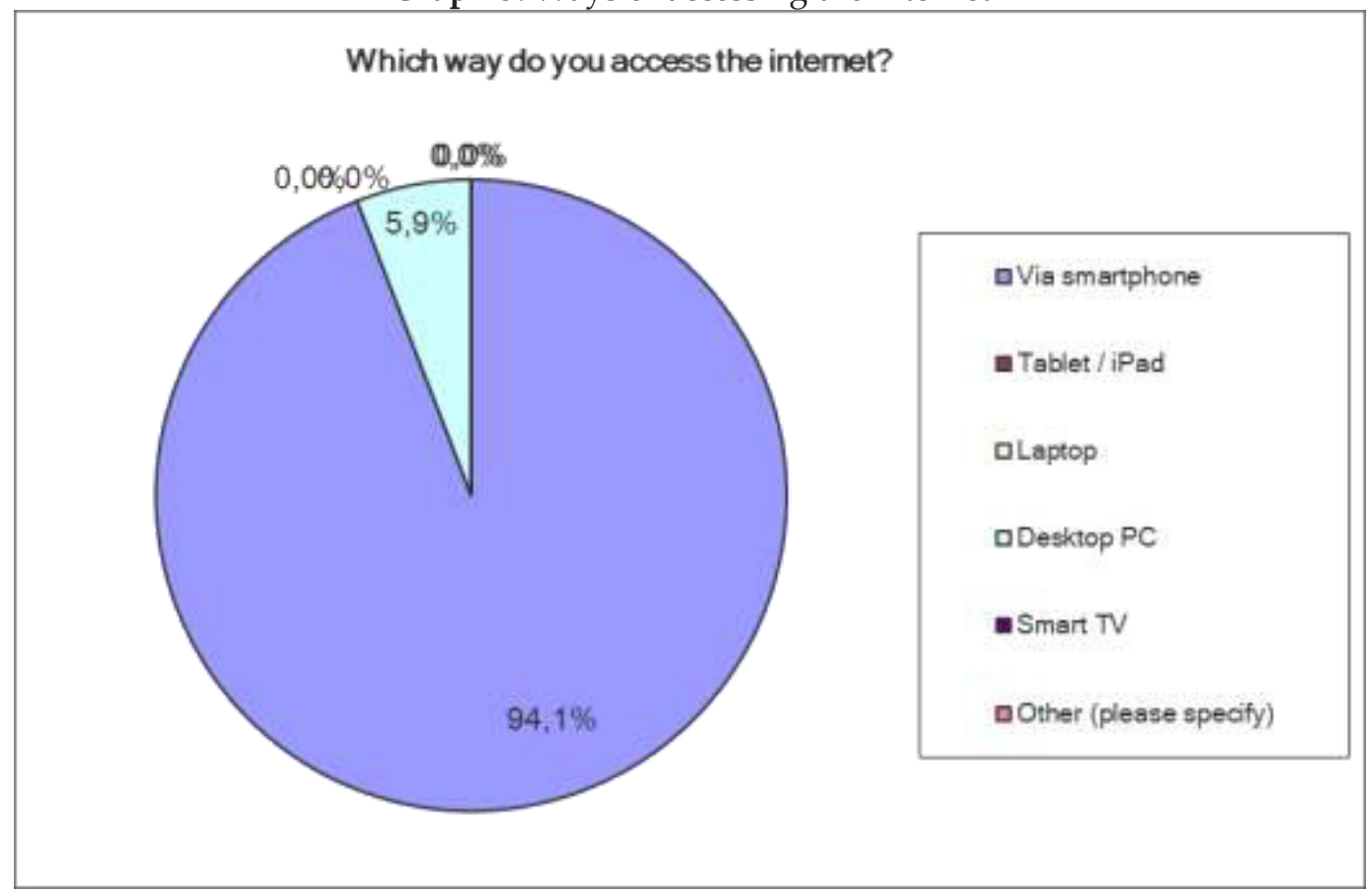

\section{Source: Own production}

"The King of Social Networks", Facebook, still predominates other social networks when it comes to usage (see Graph 4). More than a half of Croatian secondary school students (58.8\%) indicated Facebook as the primary social network, followed by Instagram $(29.4 \%$ or half less users who preferred it) and Snapchat with a still low $11.8 \%$ of primary users. It is indicative that no one had indicated a preference for any other SNS offered - Twitter, Google+, Pinterest, Tumblr and LinkedIn.

The situation changes when it comes to publishing content on social networks (see Graph 5). It is evident that by far the largest number of respondents (over 90\%) use Instagram, which is primarily a social network for publishing photos and short videos. Facebook is in second place with over $60 \%$ of answers, and the third is Snapchat again, this time with almost $30 \%$ of votes. Snapchat is a logical continuation, since it is actually a social network used primarily for photography, and then sharing photos, most of all the so-called selfie. Photos on Snapchat can then be edited, retouched or shot from the start using a particular frame that offers a variety of special effects. For example, there are fun photo shoots with dog snouts, rabbit ears, or funny hats and glasses. What used to be a long-lasting refinement of photos on Photoshop is now included and offered in advance, so that it is enough for one to smile and click a certain key. After that, photos are shared and tagged with the hashtag sign (\#).

As Rodin points out, a hashtag is any word preceeded by a tag \#, thus representing a specific searchable search item, or more precisely, leading to all content that contains that hashtag on social networks. In this form of social networking, it was first proposed for use on Twitter in 2007 as a new way of grouping messages. Its widespread expansion occurred in 2009 when Twitter added links to all hashtags and thus enabled their search /50/. 
Graph 4. Distribution of use of particular social networks

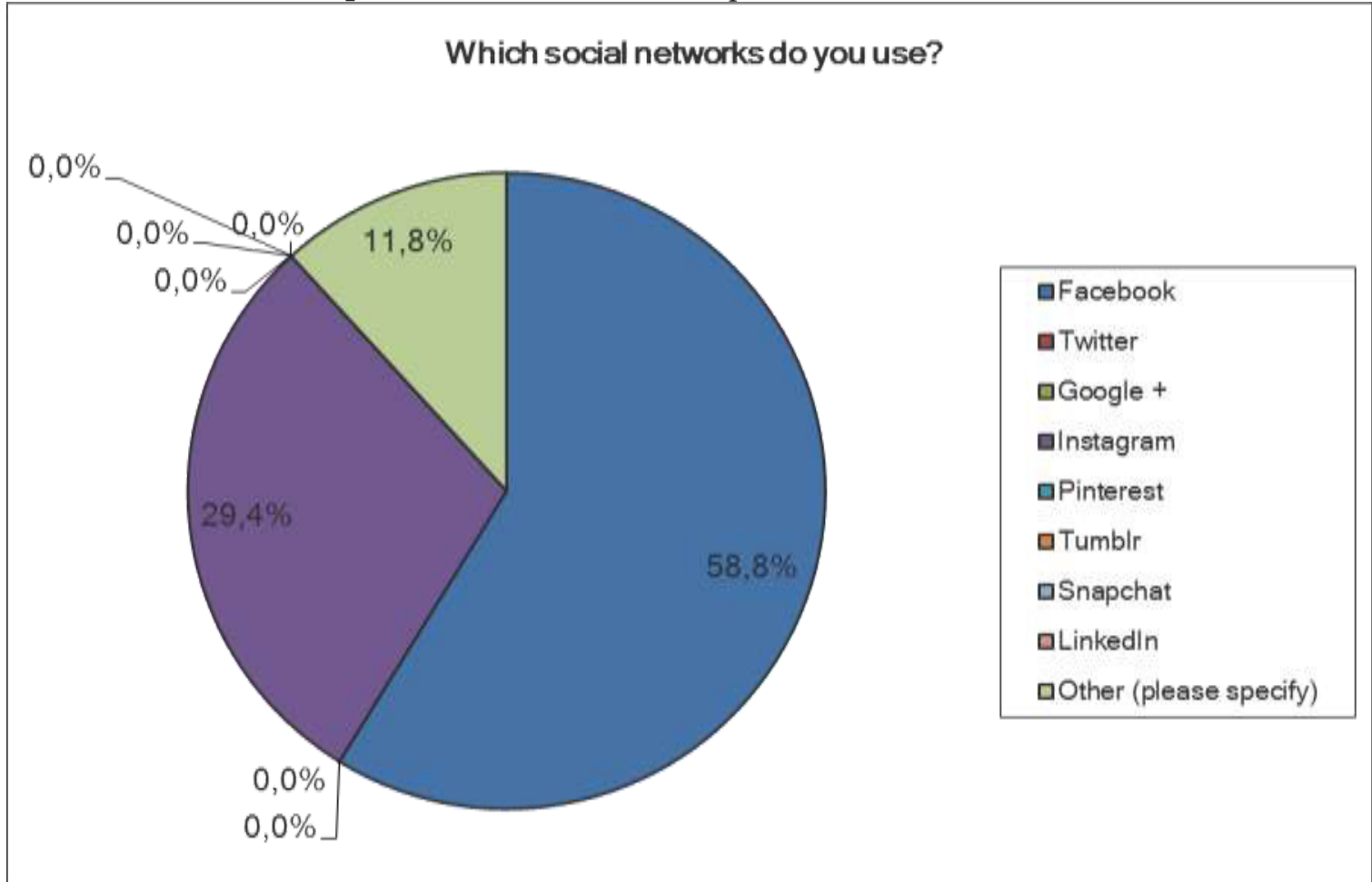

Source: Own production

Graph 5. Distribution of use of particular social networks when publishing content

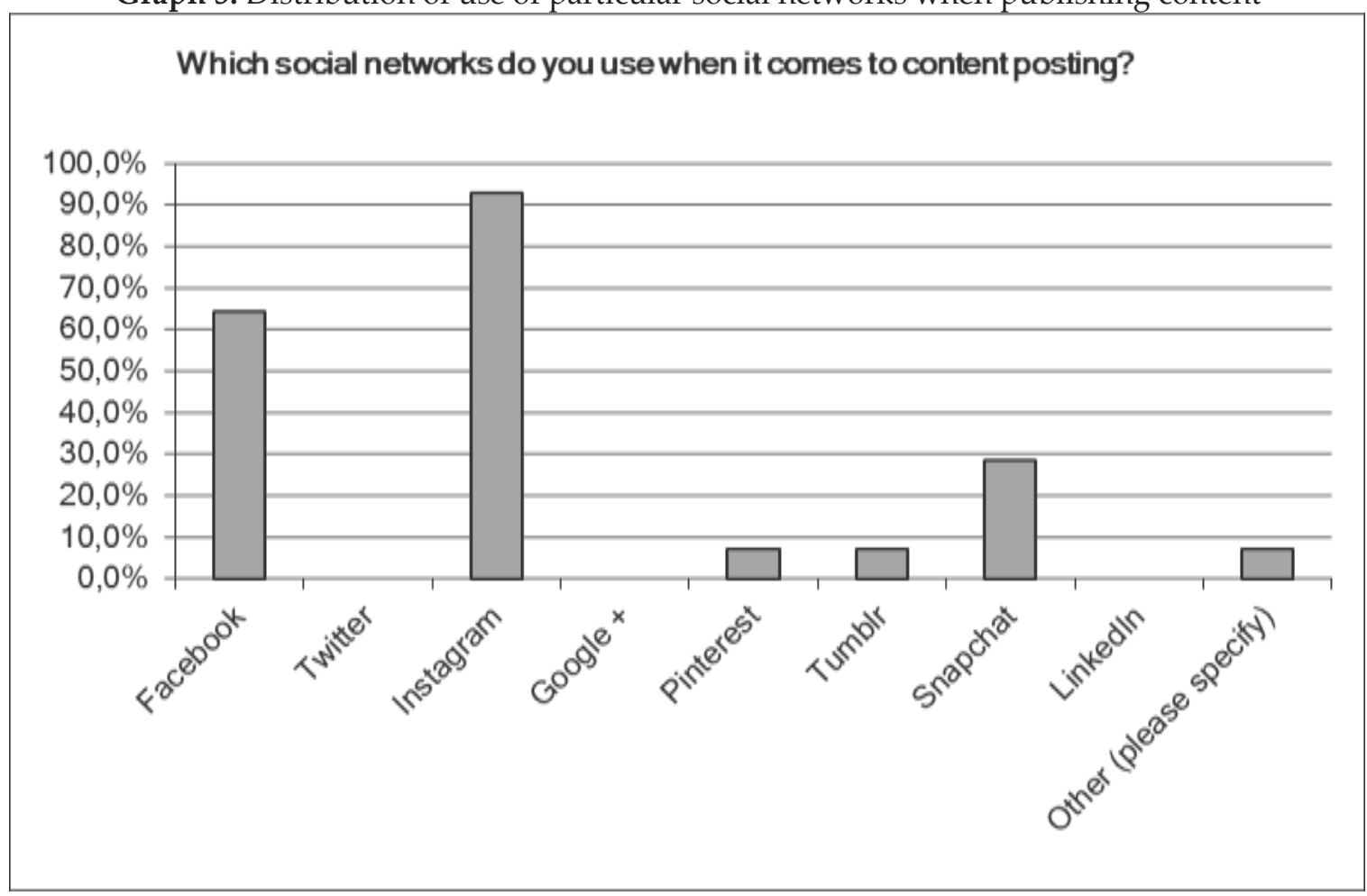

Source: Own production

When asked the open-ended question "Which social networks do you use and why?", the vast majority responded Instagram, because it was the most interesting and most transparent. Following that, they use Facebook and its messaging application - Messenger. Facebook is almost exclusively used by class and class groups so they can communicate with one another with closed 
content. Messenger is a popular communication tool for sending and receiving messages to an inbox, or a closed communication "box". Adolescents are not using Twitter or Google+ at all, because they are unattractive, they do not like the concept, find them complicated and, as they say, "no one from my crew is using them". Almost $80 \%$ of participants publish selfies and photos of their friends, and about 35\% publish photos of certain events. Approximately $14 \%$ of respondents publish music as content. Instagram is the most common answer (about 90\% of cases) to the second open-ended question "Which social network do you think is best and why?" As reasons for its preference, they state that Instagram is full of photos, it's easy to use, someone's activity is not shown, and it is currently most popular.

Graph 6. Evaluation of particular social networks
Very similar conclusions are also indicated by the ratings of individual social networks (see Graph 6), where the first three places are occupied by the same social networks, but this time in a different order: 1. Instagram, 2. Snapchat, 3. Facebook. Other SNSs are noticeably behind them, but it is interesting that even the best rated, Instagram, did not receive more than just a passing 2.6 on a scale from 1 to 5 . It can be concluded that impatient members of generation $\mathrm{Z}$ are already ready for new, even more modern social networks. It is important to point out that most respondents know of all or almost all networks. That means teenagers are curious, questioning everything, exploring everything they are offered, and then deciding what is most convenient to them or just where most of their friends are.

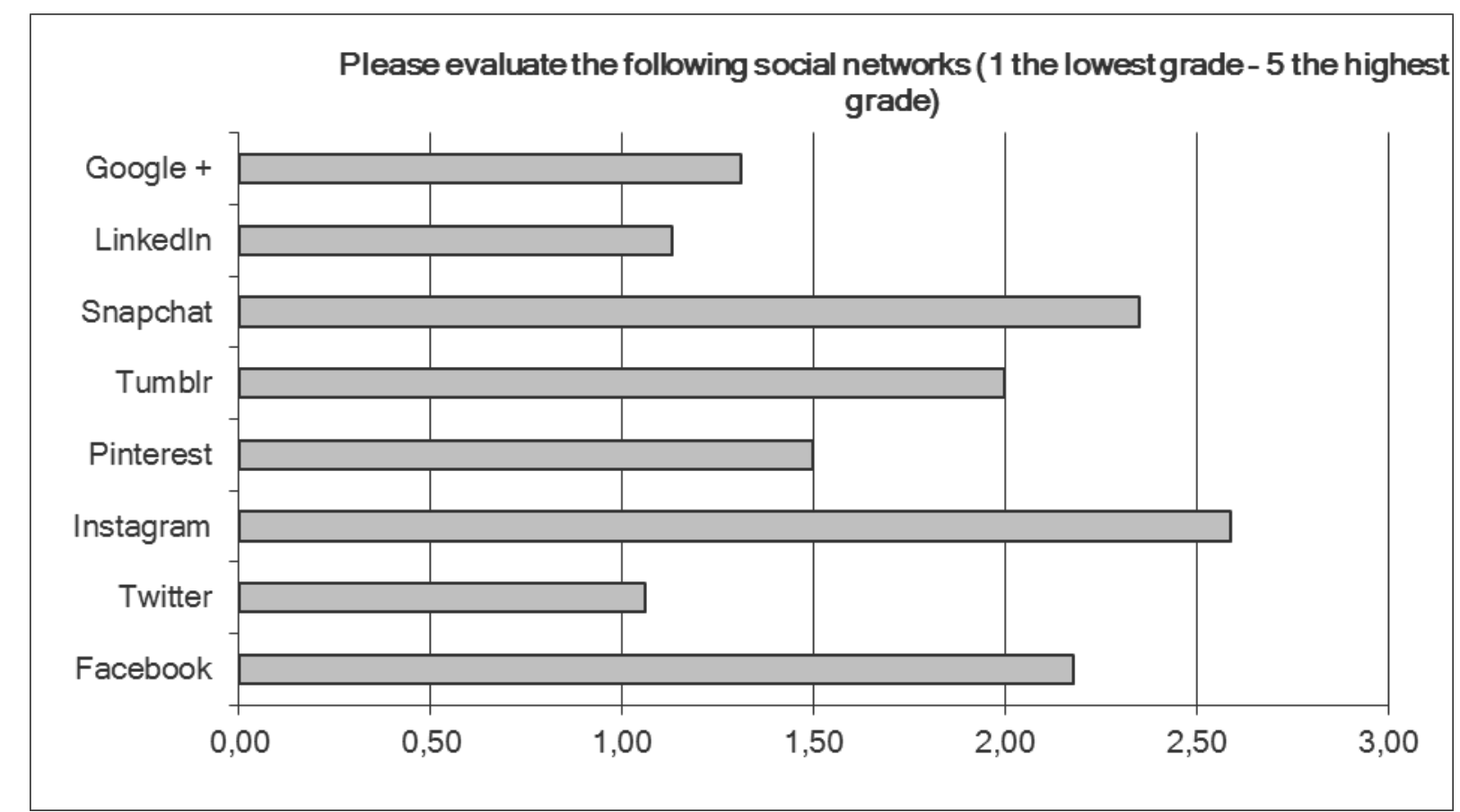

Source: Own production

Graph 7 clearly shows that among the content posted by young people, photos of them and their friends are by far the most published (in almost $80 \%$ of cases). So, respondents most often publish selfies and possibly photographs of interesting events, and a smaller share of them share or publish music.

The paradigmatic phenomenon of social networking, the selfie, is a self-portrait commonly created by a digital camera or phone camera that a person holds in their hand. Selfies, Coulthard says, are commonly and often shared on social networks such as Instagram, Snapchat or Tumblr, from which they are shared on other social networks like Facebook or Twitter. They are usually informal (casual) and are photographed with a camera held at arm's length or in a mirror. By 2013, the word selfie was so commonly used that it was included in online edition of the Oxford English Dictionary. In November of that same year, the word selfie was proclaimed to be 
Tomislav Levak, Snježana Barić Šelmić: ESCAPING THE “VIRTUAL PROMENADE” - NEW TRENDS IN USE OF SOCIAL NETWORKS BY MEMBERS OF GENERATION "Z"

Media, Culture and Public Relations, 9, 2018, 1-2, 37-55

"the word of the year" by the Oxford English Dictionary, which gave it Australian origins /51/.

Graph 7. Types of content most frequently published by participant

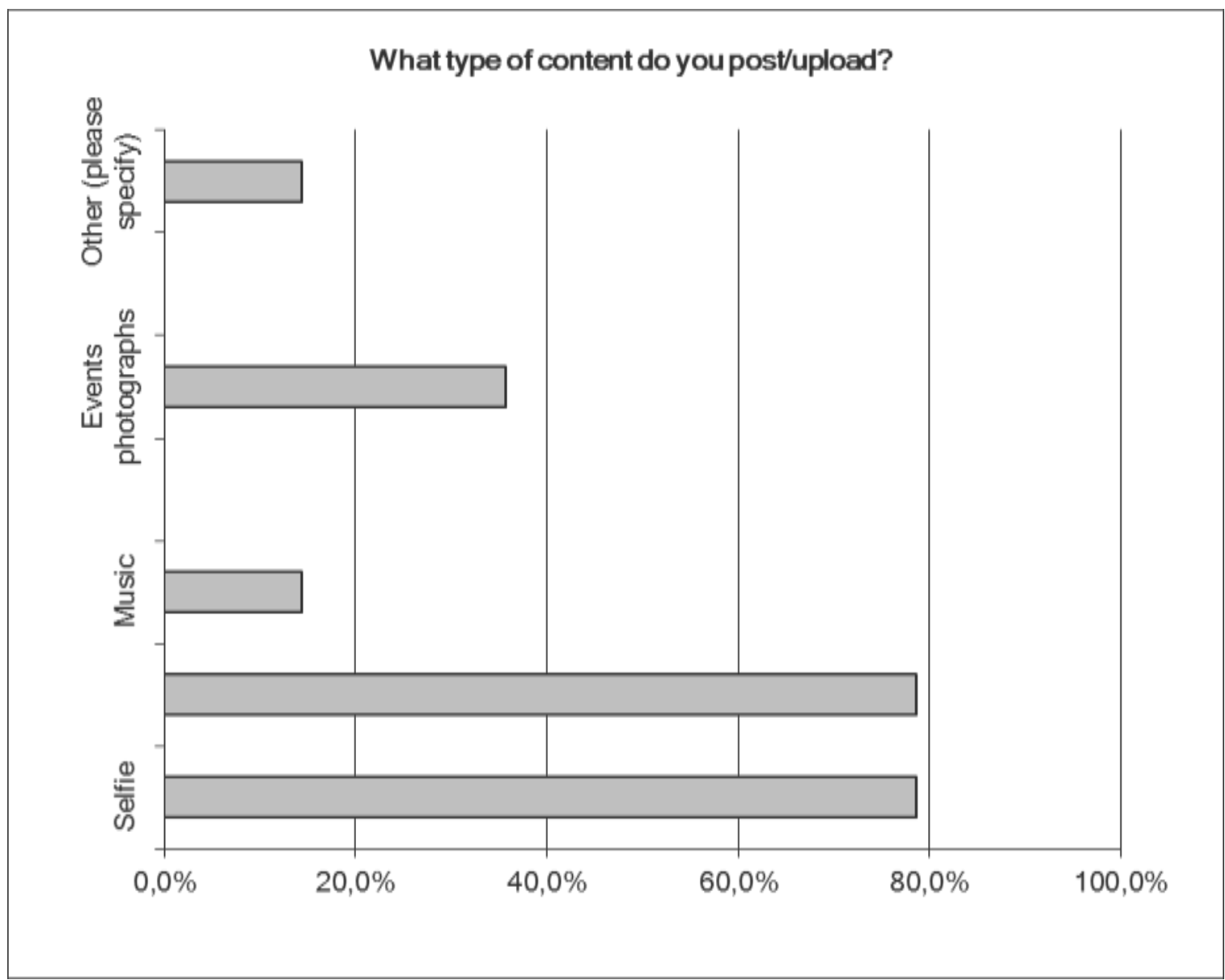

Source: Own production

Graph 8 shows that respondents are most interested in the entertainment segment - music, films, sports and news/infotainment - while, for example, they are not interested in either international or domestic politics. What is worrying is that they are extremely uninterested in culture and education. It is yet another proof that this is factually an instant generation, whose interests then also reflect on social networks. 


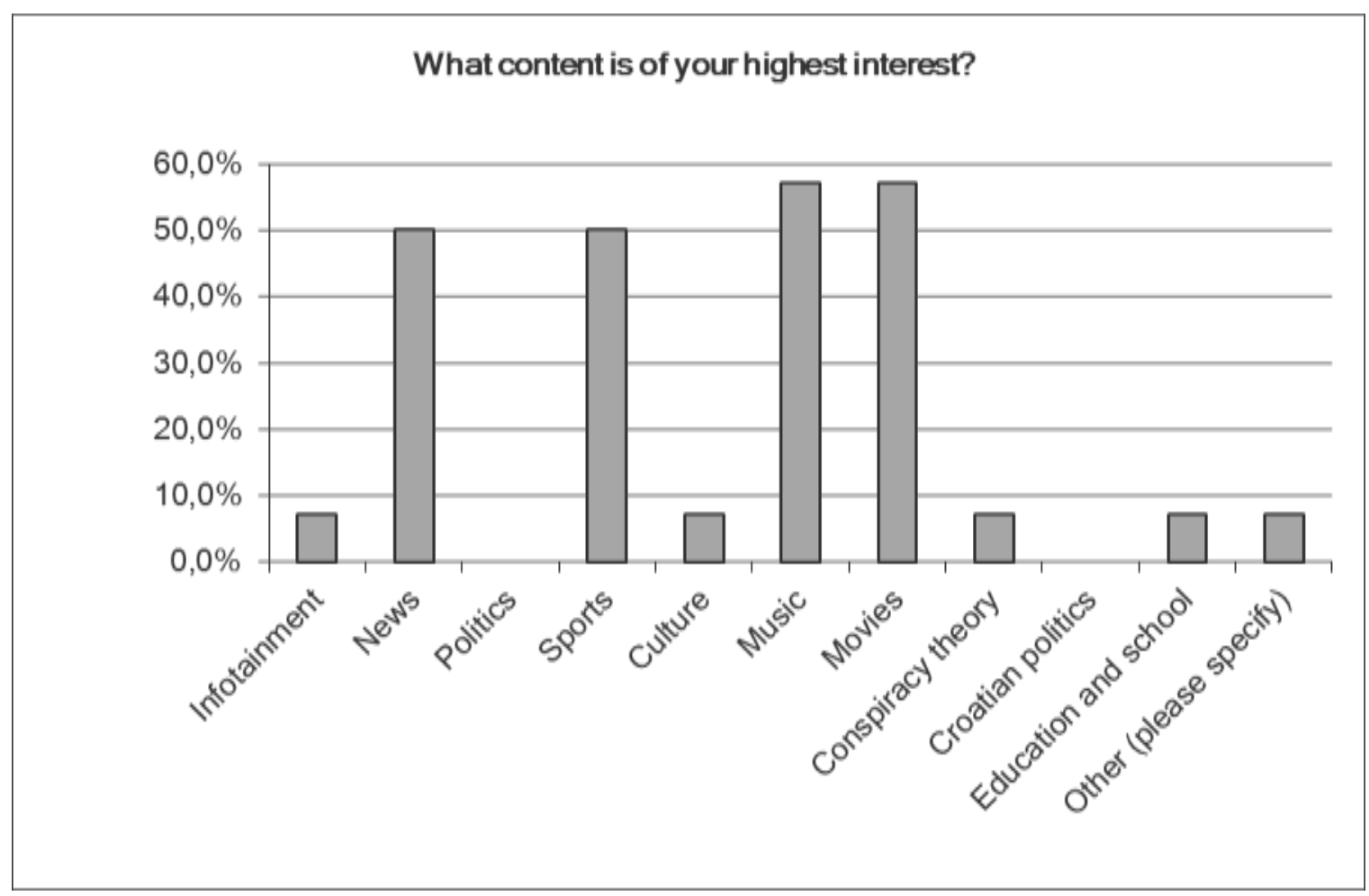

Source: Own production

When it comes to social networking apps (see Graph 9), it is likely that young Croatian men and women are closely following global trends. Messenger is in the first place, immediately followed by WhatsApp. Participants use Viber much less, even less than SMS, which is a much older "tool". It can be concluded that Messenger has completely replaced the phone call, in the classic meaning of the word. Communication is reduced to writing short messages, with a handful of emoticons and abbreviations. However, this paper will not deal with this topic, because it would require a more in-depth penetration in the field of lingvistics and semiotics.

Graph 9. Distribution of use of particular social networking apps

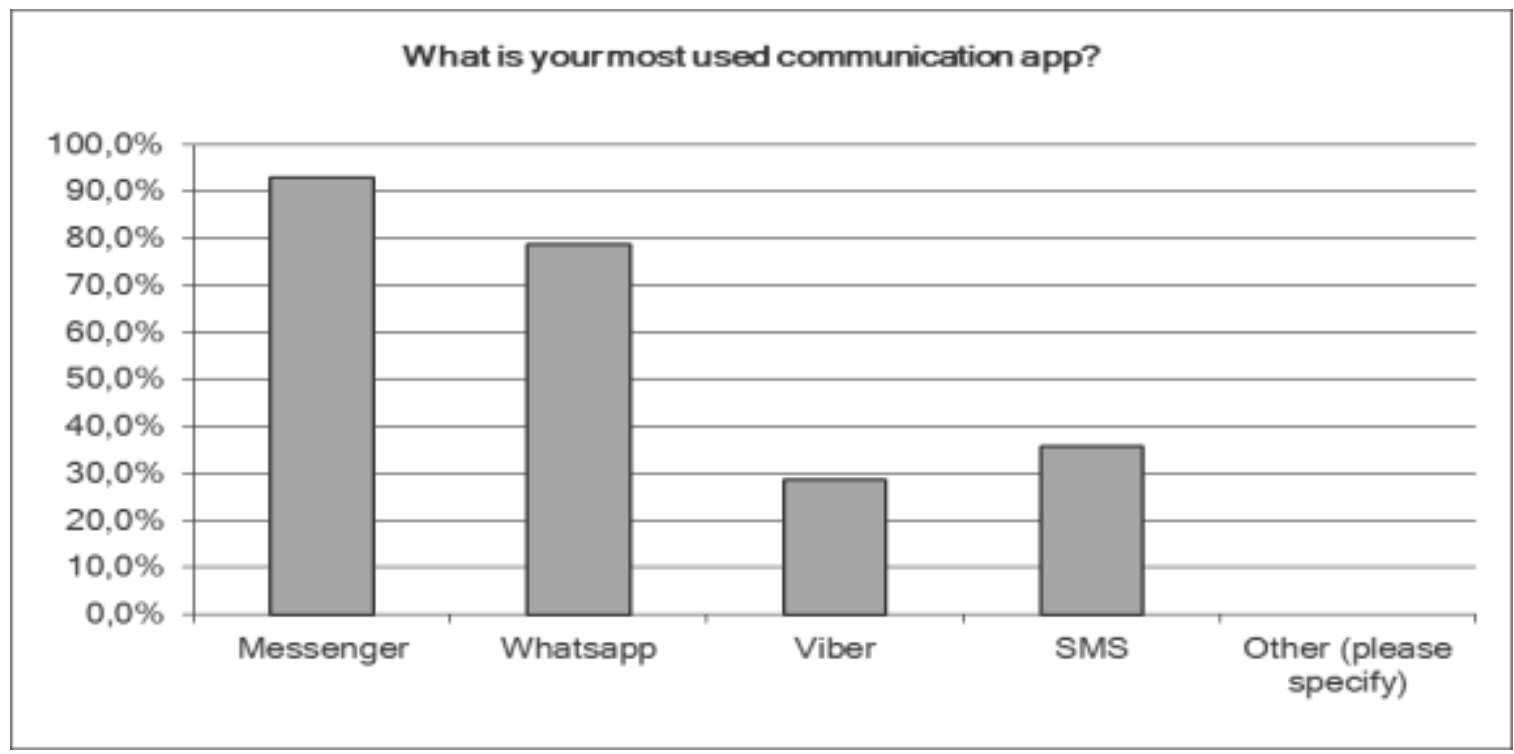

Source: Own production 
The results of the responses to the question dealt with in Graph 10 are not surprising. Parents of generation $\mathrm{Z}$ members are "digital immigrants" who have been trained to use new media and adapted to social networking. While their children find that to be the main and most important way of socialization and belonging to a community, "digital immigrants" as young people believe - use social networks (according to the participants, almost exclusively Facebook) mostly for entertainment and leisure. Facebook is the social network most commonly used by both parents and children (see Graph 11).

Graph 10. Distribution of use of particular social networs by participants' parents

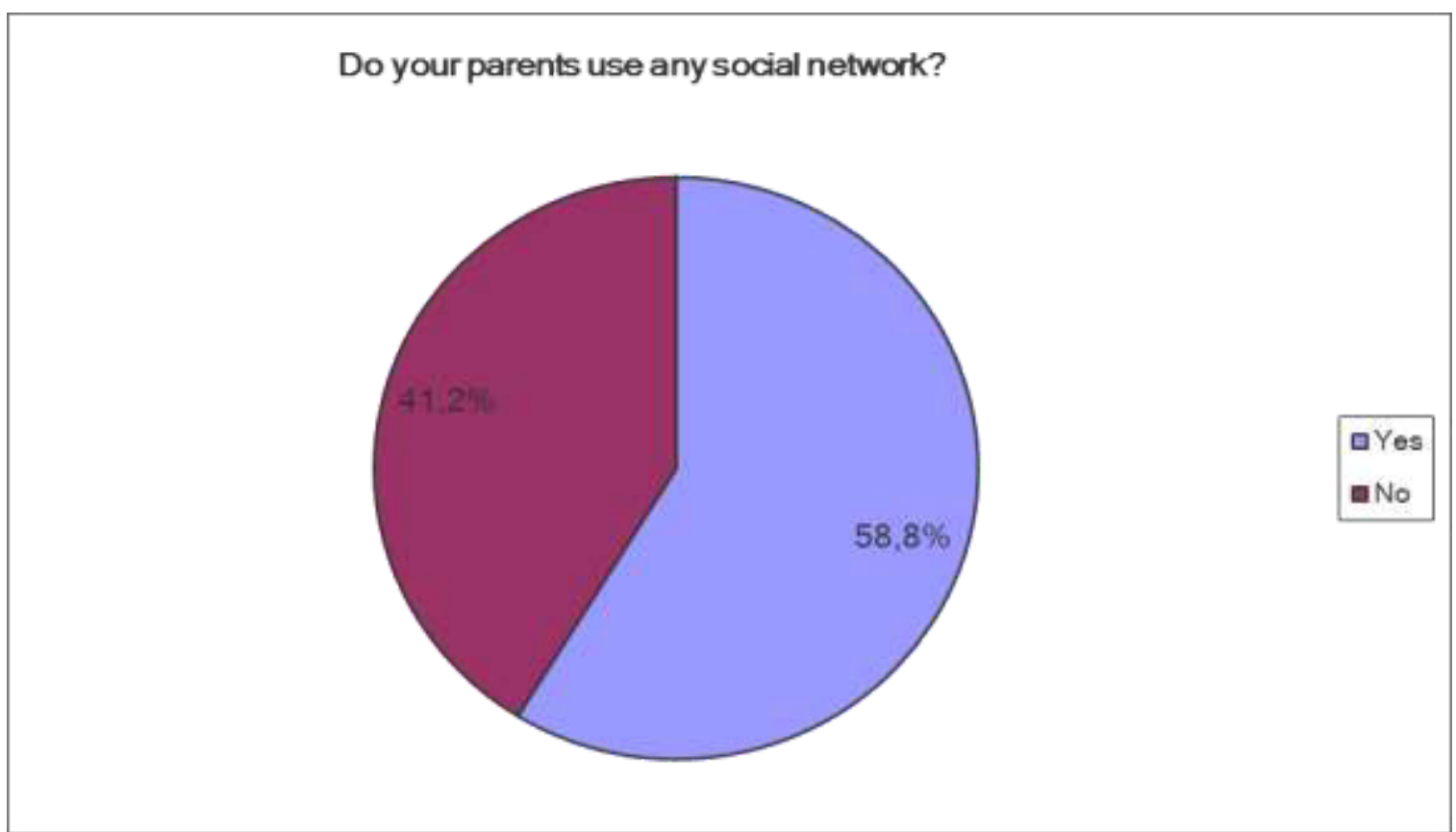

Source: Own production

Graph 11. Percentage of use of the same social network by participants and their parents

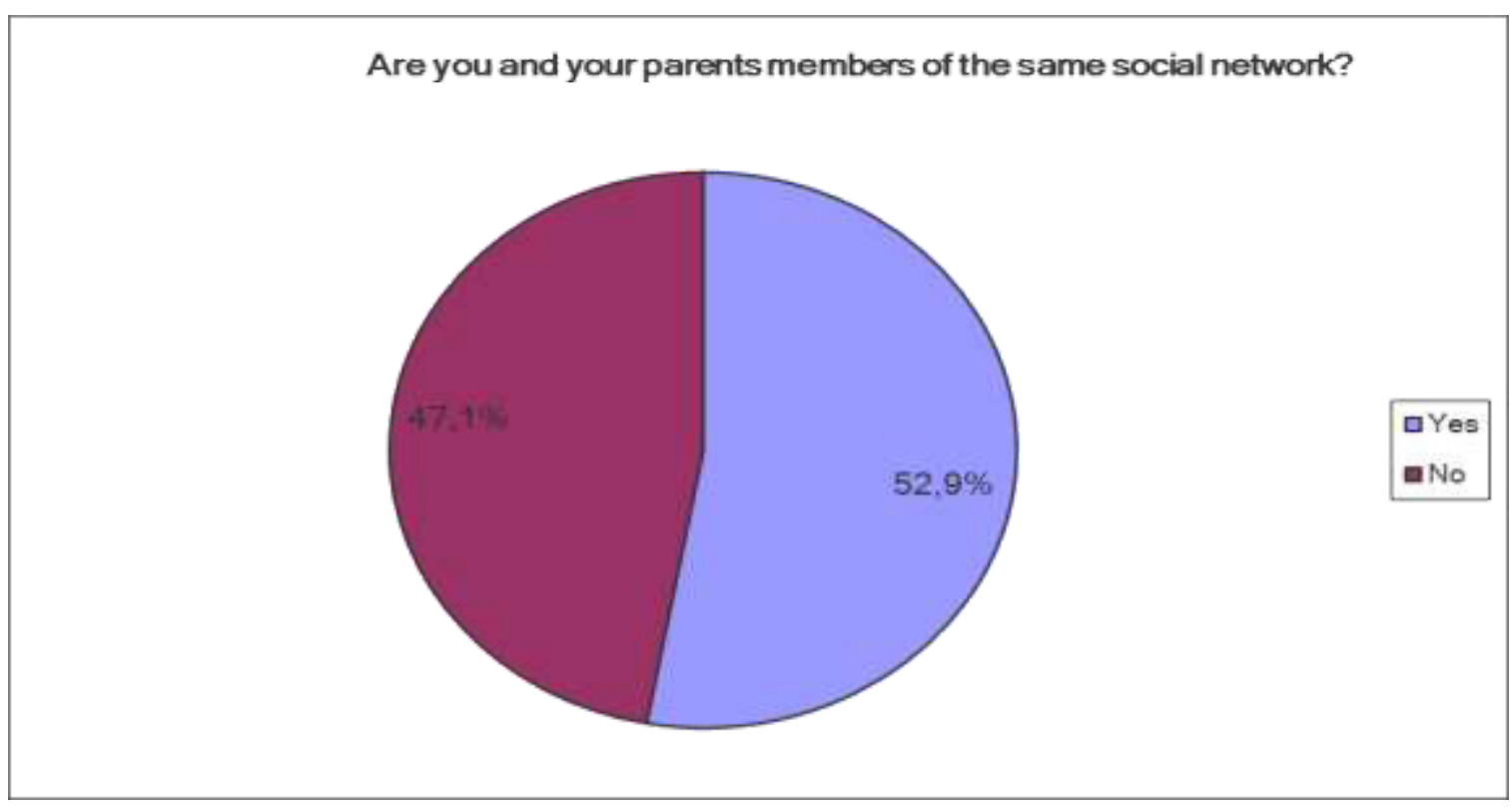

Source: Own production 
To open type questions "Do you feel that Facebook has become crowded?" and "Do you feel there is too much overwhelming content?", the participants responded mostly positively. Within that, they are less concerned about the fact that older family members have "moved" to Facebook, because they do not actually spend time there. Namely, they use the "Messenger" communication tool, and if they are on Facebook, they almost exclusively stay within their closed groups without public exposure. They are more concerned that Facebook, according to some, became "boring and non-transparent". However, they agree that the fact that there are different generations on Facebook now leads to the crowding of different content, which may be interesting to older generations, but not to generation $\mathrm{Z}$. Such findings are in line with the findings of the iZone agency's research from the end of 2016, which was, among other things, conducted among 1027 respondents of different age groups. However, in this research, for example, young people have highlighted that Snapchat users enjoy the greatest privacy $(65.7 \%)$ and Facebook users the smallest (41.9\%) /52/, which is obviously another reason why they are increasingly "migrating" to more modern social networks.

\section{Conclusion}

The research results confirmed the initial hypotheses of the authors: members of generation $\mathrm{Z}$ are increasingly leaving Facebook as a "virtual promenade", largely because of older generations, including their parents, had started to use it. The young mostly turn to social networks that offer them a prevalence of images over text, in accordance with the fact that this is a predominantly visual age and an age of instant value of time (one of the characteristics of generation Z). These are, primarily, more modern, faster and (visually) more interesting social networks, such as Instagram, which they find adequate because it is easy to process and publish photos or video clips, or even Snapchat, which offers a limited 24-hour duration of all content.

In addition, the analysis of the responses indicated that there were no significant differences in preference among members of generation $\mathrm{Z}$ in larger urban areas on the continent and in smaller urban areas on the Adriatic islands. This leads to the conclusion that globalization has gained ground in Croatia, as trends and events are no longer different in larger urban environments from those in more isolated environments, specifically islands.

As Rotar Zgrabljić emphasizes, "the changes in audiences created under the influence of digitized media are considered not only as a change of the concept of passive audience to an active audience, but above all as a change from an active to an interactive audience." /53/. Her claim is equally valid for post-modern era of visual and digital culture, and for social networks, the most popular of which are those that offer the youngest generations to easily handle the visual elements of new communication technologies. Photographs, selfies, and video clips are the core of communication today, which, most of all among young people, takes place almost without text. Today, members of generation $\mathrm{Z}$ communicate almost exclusively with images and hashtags, and for that purpose they also seek appropriate social networks.

Notes

/1/ DreamGrow (2017). About DreamGrow, 11 February 2008. https://www.dreamgrow.com/about/ (accessed: 2 July 2017)

/2/ Murse T. (2017). Why the Facebook Limit Age Is 13. ThoughtCo, $23 \quad$ January 2017. https://www.thoughtco.com/does-facebook-haveage-restrictions-3367671 (accessed: 8 July 2017.)

/3/ Kallas P. (2017). Top 15 Most Popular Social Networking Sites and Apps (July 2017). DreamGrow, 13 July 2017. https://www.dreamgrow.com/top-15most-popular-social-networking-sites/ (accessed: 15 July 2017)

14/ Tportal (2016). Gotovo svaki drugi stanovnik Hrvatske koristi društvene mreže [Almost every other inhabitant in Croatia uses social networks]. 1 February 2016. https://www.tportal.hr/tehno/clanak/gotovosvaki-drugi-stanovnik-hrvatske-koristi-drustvenemreze-20160201 (accessed: 9 July 2017)

/5/ Vitas Z. (2016). U Hrvatskoj je više od 1,9 milijuna ljudi aktivno na Facebooku [Over 1.9 million people in Croatia are active on Facebook], Večernji list, 1 December 2016. https://www.vecernji.hr/techsci/uhrvatskoj-je-vise-od-19-milijuna-ljudi-aktivno-nafacebooku-1132516 (accessed: 6 July 2017)

16/ Teen385 (2014). Tinejdžeri napuštaju Facebook - znate li na koje mreže odlaze? [Teenagers abandoning Facebook - do you know which networks they are leaving for?]. 22 August 2014. http://www.teen385.com/techno/noviteti/tinejdzerinapustaju-facebook-znate-li-na-koje-mreze-odlaze (accessed: 3 July 2017) 
/7/ Plavljanić B. (2012). Povijest društvenih mreža [History of social networks]. PC Chip (196), 27 June 2012, p. 17

/8/ Boyd D.M.; Ellison N.B. (2007). Social network sites: Definition, history and scholarship, pp. 210-230, in: Herring, Susan (ed.) Journal of Computer-Mediated Communication, Volume 13, Issue 1. Hoboken, New Jersey (USA), Oxford (UK): Wiley-Blackwell, p. 211

19/ Plavljanić B. (2012). Povijest društvenih mreža [History of social networks]. PC Chip (196), 27 June 2012, p. 17

/10/ Manovich L. (2001) The Language of New Media. Cambridge, Massachusetts. London, England: MIT Press, Foreword, p. 10

/11/ Boyd D.M., Ellison N.B. (2007). Social network sites: Definition, history and scholarship, pp. 210230, in: Herring, Susan (ed.) Journal of ComputerMediated Communication, Volume 13, Issue 1. Hoboken, New Jersey (USA), Oxford (UK): WileyBlackwell, p. 220

/12/ Boyd-Barret O. (2004). U.S. Global Cyberspace, pp. 19-42, in: Schuler, D.; Day P. (eds.) Shaping the Network Society: the New Role of Civil Society in Cyberspace. Cambridge, London: The MIT Press, p. 21

/13/ Uzelac A. (2008). Informacijsko društvo - tržište ili civilno društvo? [Information society - market or civil society], pp. 75-104, in: Peruško, Zrinjka (ed.). Mediji, kultura i civilno društvo [Media, culture and civil society]. Zagreb: Naklada Jesenski i Turk and Hrvatsko sociološko društvo, p. 79

/14/ Labaš D. (2009). Međuljudska komunikacija, novi mediji i etika [Interhuman communication, new media and ethics], pp. 13-40, in: Labaš, Danijel (ed.). Novi mediji - nove tehnologije - novi moral [New media - new technologies - now morality] (proceedings from Round table with international participation). Zagreb: Hrvatski studiji Sveučilišta u Zagrebu, p. 13

/15/ Riva G. (2004). Psicologia dei nuovi media [Psychology of new media]. Bologna: Il Mulino, p. 15

/16/ Labaš D. (2009). Međuljudska komunikacija, novi mediji i etika [Interhuman communication, new media and ethics], pp. 13-40, in: Labaš, Danijel (ed.). Novi mediji - nove tehnologije - novi moral [New media - new technologies - now morality] (proceedings from Round table with international participation). Zagreb: Hrvatski studiji Sveučilišta u Zagrebu, p. 14

/17/ Negroponte N. (2002). Biti digitalan [Being digital]. Zagreb: Sysprint, p. 27

/18/ Labaš D. (2009). [Interhuman communication, new media and ethics], pp. 13-40, in: Labaš, Danijel (ed.). Novi mediji - nove tehnologije - novi moral [New media - new technologies - now morality] (proceedings from Round table with international participation). Zagreb: Hrvatski studiji Sveučilišta u Zagrebu, pp. 15-19

/19/ ibid., p. 26
/20/ Tjurou J. (Turow, Joseph) (2012). Mediji danas: Uvod u masovne komunikacije [Media today: Introducton into mass communication]. Belgrade: Clio, p. 19

/21/ Šišak M., (2009). Javnost i novi mediji [The public and new media], pp. 77-94, in: Labaš, Danijel (ed.). Novi mediji - nove tehnologije - novi moral [New media - new technologies - now morality] (proceedings from Round table with international participation). Zagreb: Hrvatski studiji Sveučilišta u Zagrebu, p. 87

/22/ McQuail D. (2005). Mass Communication Theory (fifth edition). London: SAGE Publications, p. 138

/23/ Tancer B. (2010). Klik - što milijuni ljudi rade na internetu $i$ što to govori o njima [Click - what millions of people do on the Internet and what it says about them]. Zagreb: Algoritam, p. 125

/24/ Kirkpatrick D. (2010). The Facebook Effect. New York (USA): Simon\&Schuster Paperbacks, p. 274

/25/ Brooker P., Dutton W., Greiffenhagen C. (2017). What would Wittgenstein say about social media?, pp. 1-17, in: SAGE Journals, 22 June 2017. http://journals.sagepub.com/doi/10.1177/1468794117 713058 (accessed: 27 June 2017)

/26/ Kallas P. (2017). Top 15 Most Popular Social Networking Sites and Apps (July 2017). DreamGrow, 13 july 2017. https://www.dreamgrow.com/top-15most-popular-social-networking-sites/ (accessed: 15 July 2017)

/27/ Rouse M. (2014). Facebook: Definition. WhatIs.com, August 2014. http://whatis.techtarget.com/definition/Facebook (accessed: 12 July 2017)

/28/ Briggs A., Burke P. (2011). Socijalna povijest medija: od Gutenberga do interneta [The social history of media: from Gutenberg to the Internet]. Zagreb: Naklada Pelago, p. 334

129/ Mezrich B. (2010). Slučajni milijarderi: Kako je osnovan Facebook [Accidental Billionaires: How Facebook was founded]. Zagreb: Znanje, p. 262

/30/ Media Marketing (2017). Infografika: Zašto je Facebook $i$ dalje kralj društvenih mreža u Hrvatskoj [Infograph: Why Facebook is still the king of social networks in Croatia], 28 February 2017. http://www.media-marketing.com/temasedmice/infografika-zasto-je-facebook-i-dalje-kraljdrustvenih-mreza-u-hrvatskoj/ (accessed: 2 July 2017)

/31/ Reić A. (2015). Nova generacija mladih - generacija $\mathrm{Z}$ [New generation of youth - generation Z]. Europa.eu, $\quad 12 \quad$ November 2015. https://europa.eu/youth/hr/article/39/31499_fi (accessed: 10 July 2017)

/32/ Socialmarketing.org (2017). Generations X, Y, Z and the Others. WYSchroer, February 2017. http://socialmarketing.org/archives/generations-xyz-and-the-others/ (accessed: 13 July 2017)

/33/ ibid. 
/34/ Reić A. (2015). Nova generacija mladih - generacija $\mathrm{Z}$ [New generation of youth - generation Z]. Europa.eu, $\quad 12 \quad$ November 2015. https:/europa.eu/youth/hr/article/39/31499_fi (accessed: 10 July 2017)

/35/ ibid.

/36/ Castells M. (2010). The Rise of the Network Society: The Information Age: Economy, Society and Culture (Volume 1, Second Edition). Malden (USA), Oxford (UK): Wiley-Blackwell, p. 353

/37/ Prensky M. (2001). Digital Natives, Digital Immigrants (Part 1), pp. 1-6, in: On The Horizon, Vol. 9, No. 5. Bingley (UK): MCB University Press, pp. 1-2

/38/ ibid., p. 2

139/ Castells M. (2010). The Rise of the Network Society: The Information Age: Economy, Society and Culture (Volume 1, Second Edition). Malden (USA), Oxford (UK): Wiley-Blackwell, p. 353

/40/ Pelivan A. (2017). Više nismo guske u magli kad su u pitanju društvene mreže [When it comes to social networks we are no longer geese in the fog]. Media Marketing, February 2017. http://www.mediamarketing.com/tema-sedmice/vise-nismo-guske-umagli-kad-su-u-pitanju-drustvene-mreze/ (accessed: 12 July 2017)

/41/ Collier D. (1993). The Comparative Method, pp. 105-119, in: Finifter, Ada W. (ed.) Political Science: The State of Discipline II. Washington, D.C (USA): American Political Science Association, p. 105

/42/ Žugaj M., Dumičić K., Dušak V. (2006). Temelji znanstvenoistraživačkog rada: Metodologija i metodika [The foundations of scientific research: Methodology and methodics] (second amended and revised edition). Varaždin: Fakultet organizacije i informatike

/43/ Croatian Bureau of Statistics (2016). Priopćenje br. 8.1.3. [Communication No. 8.1.3.], 26 April 2016. www.dzs.hr (accessed: 22 April 2017)

/44/ Croatian Bureau of Statistics (2012). Popis stanovništva Republike Hrvatske 2011 [Census of the Republic of Croatia 2011]. http://www.dzs.hr/Hrv/censuses/census2011/results/htm /H01_01_01/H01_01_01.html (accessed: 16 April 2017)

/45/ ibid.

/46/ Kallas P. (2017). Top 15 Most Popular Social Networking Sites and Apps (January 2017). DreamGrow, 13 January 2017. https://www.dreamgrow.com/top15-most-popular-social-networking-sites/ (accessed: 15 July 2017)

/47/ Pelivan A. (2017). Više nismo guske u magli kad su u pitanju društvene mreže [When it comes to social networks we are no longer geese in the fog]. Media Marketing, February 2017. http://www.mediamarketing.com/tema-sedmice/vise-nismo-guske-umagli-kad-su-u-pitanju-drustvene-mreze/ (accessed: 12 July 2017)
/48/Croatian Bureau of Statistics (2012). Popis stanovništva Republike Hrvatske 2011 [Census of the Republic of Croatia 2011]. http://www.dzs.hr/Hrv/censuses/census2011/results/htm /H01_01_01/H01_01_01.html (accessed: 16 April 2017)

/49/ Jobs S. (2007). Steve Jobs Introducing the iPhone at MacWorld 2007 (14:05'). YouTube, 9 January 2007. https://www.youtube.com/watch?v=x7qPAY9JqE4 (accessed: 3 July 2017)

/50/ Rodin Z. (2016). Što je hashtag \# i čemu služi [What is a hashtag \# and what is it used for]. BizIT.hr, 12 January 2016. https://www.bizit.hr/sto-je-hashtag-icemu-sluzi/ (accessed: 11 July 2017)

/51/ Coulthard C. (2013). Self-portraits and social media: The rise of the "selfie“. BBC News, 7 June 2013. http://www.bbc.co.uk/news/magazine-22511650 (accessed: 17 June 2017)

/52/ Pelivan A. (2017). Više nismo guske u magli kad su $\mathrm{u}$ pitanju društvene mreže [When it comes to social networks we are no longer geese in the fog]. Media Marketing, February 2017. http://www.mediamarketing.com/tema-sedmice/vise-nismo-guske-umagli-kad-su-u-pitanju-drustvene-mreze/ (accessed: 12 July 2017)

/53/ Zgrabljić Rotar N. (2011). Masovni mediji i digitalna kultura [Mass media and digital culture], pp. 2551, in: Zgrabljić Rotar, Nada (ed.). Digitalno doba: masovni mediji $i$ digitalna kultura [Digital age: mass media and digital culture]. Zadar: Sveučilište u Zadru and Naklada Medijska istraživanja, p. 33

Literature

1. Baudrillard, J. (2013). Simulacija i zbilja [Simulation and reality]. Zagreb: Jesenski i Turk

2. Boyd-Barret, O. (2004). U.S. Global Cyberspace, pp. 19-42, in: Schuler, D.; Day P. (eds.) Shaping the Network Society: the New Role of Civil Society in Cyberspace. Cambridge, London: The MIT Press

3. Boyd, D. M.; Ellison, N. B. (2007). Social network sites: Definition, history and scholarship, pp. 210230, in: Herring, Susan (ed.) Journal of ComputerMediated Communication, Volume 13, Issue 1. Hoboken, New Jersey (USA), Oxford (UK): WileyBlackwell

4. Briggs, A.; Burke, P. (2011). Socijalna povijest medija: od Gutenberga do interneta [The social history of media: from Gutenberg to the Internet]. Zagreb: Naklada Pelago

5. Brooker, P.; Dutton, W.; Greiffenhagen C. (2017). What would Wittgenstein say about social media?, pp. 1-17, in: SAGE Journals, 22 June 2017. http://journals.sagepub.com/doi/10.1177/1468794117 713058 (accessed: 27 June 2017)

6. Castells, M. (2010). The Power of Identity: The Information Age: Economy, Society and Culture (Volume 1, 
Second Edition). Malden (USA), Oxford (UK):

Wiley-Blackwell

7. Castells, M. (2010). The Rise of the Network Society: The Information Age: Economy, Society and Culture (Volume 1, Second Edition). Malden (USA), Oxford (UK): Wiley-Blackwell

8. Collier, D. (1993). The Comparative Method, pp. 105-119, in: Finifter, Ada W. (ed.) Political Science: The State of Discipline II. Washington, D.C (USA): American Political Science Association

9. Coulthard, C. (2013). Self-portraits and social media: The rise of the "selfie“. BBC News, 7 June 2013. http://www.bbc.co.uk/news/magazine-22511650 (accessed: 17 June 2017)

10. Cvjetičanin, B. (2014). Kultura u doba mreža [Culture in the time of networks]. Zagreb: Hrvatska sveučilišna naklada

11. Croatian Bureau of Statistics (2012). Popis stanovništva Republike Hrvatske 2011 [Census of the Republic of Croatia 2011]. http://www.dzs.hr/Hrv/censuses/census2011/results/htm /H01_01_01/H01_01_01.html (accessed: 16 April 2017)

12. Croatian Bureau of Statistics (2016). Priopćenje br. 8.1.3. [Communication No. 8.1.3.], 26 April 2016. www.dzs.hr (accessed: 22 April 2017)

13. DreamGrow (2017). About DreamGrow, 11 February 2008. https://www.dreamgrow.com/about/ (accessed: 2 July 2017)

14. Giddens, A. (1991). Modernity and Self-Identity: Self and Society in the Late Modern Age. Stanford (USA): Stanford University Press

15. Greenspan, A. (2008). Authoritas. Palo Alto (USA): Think Press

16. Hromadžić, H. (2008). Konzumerizam - Potreba, životni stil, ideologija [Consumerism - Need, lifestlye, ideology]. Zagreb: Naklada Jesenski i Turk

17. James, W. (2013). Stanford Encyclopedia of Philosophy (Second Edition). Stanford (USA): Center for the Study of Language and Information, Standford University

18. Jarvis, J. (2009). What Would Google Do?. New York (USA): HarperCollins Publishers

19. Jobs, S. (2007). Steve Jobs Introducing the iPhone at MacWorld 2007 (14:05'). YouTube, 9 January 2007.

https://www.youtube.com/watch?v=x7qPAY9JqE4 (accessed: 3 July 2017)

20. Kallas, P. (2017). Top 15 Most Popular Social Networking Sites and Apps (July 2017). DreamGrow, 13 July 2017. https://www.dreamgrow.com/top15-most-popular-social-networking-sites/ (accessed: 15 July 2017)

21. Kirkpatrick, D. (2010). The Facebook Effect. New York (USA): Simon\&Schuster Paperbacks

22. Labaš, D. (2009). Međuljudska komunikacija, novi mediji i etika [Interhuman communication, new media and ethics], pp. 13-40, in: Labaš, Danijel (ed.). Novi mediji - nove tehnologije - novi moral [New media - new technologies - now morality] (proceedings from Round table with international participation). Zagreb: Hrvatski studiji Sveučilišta u Zagrebu

23. Manovich, L. (2001) The Language of New Media. Cambridge, Massachusetts. London, England: MIT Press

24. McQuail, D. (2005). Mass Communication Theory (fifth edition). London: SAGE Publications

25. Media Marketing (2017). Infografika: Instagram $i$ Twitter: Lijepe fotografije ipak pobjeđuju corkutanje [Infograph: Instagram and Twitter: Pretty photos winning over tweets], 2 March 2017. http://www.media-marketing.com/temasedmice/infografika-lijepe-fotografije-pobjedujucvrkutanje/ (accessed: 9 July 2017)

26. Media Marketing (2017). Infografika: Snapchat i Google+ - za mlade $i$ za one malo manje mlade [Infograph: Snapchat and Google+ - for the young and the not so young], 1 March 2017. http://www.media-marketing.com/temasedmice/infografika-snapchat-i-google-za-mlade-iza-one-malo-manje-mlade/ (accessed: 10 July 2017)

27. Media Marketing (2017). Infografika: Zašto je Facebook i dalje kralj društvenih mreža u Hrvatskoj [Infograph: Why Facebook is still the king of social networks in Croatia], 28 February 2017. http://www.media-marketing.com/temasedmice/infografika-zasto-je-facebook-i-daljekralj-drustvenih-mreza-u-hrvatskoj/ (accessed: 2 July 2017)

28. Mezrich, B. (2010). Slučajni milijarderi: Kako je osnovan Facebook [Accidental Billionaires: How Facebook was founded]. Zagreb: Znanje Morozov, Evgeny (2012). The Net Delusion: The Dark Side of Internet Freedom. Springfield, Missouri (USA): Paperback Press Publishing

29. Morozov, E. (2012). The Net Delusion: The Dark Side of Internet Freedom. Springfield, Missouri (USA): Paperback Press Publishing

30. Murse, T. (2017). Why the Facebook Limit Age Is 13. ThoughtCo, 23 January 2017. https://www.thoughtco.com/does-facebook-haveage-restrictions-3367671 (accessed: 8 July 2017)

31. Negroponte, N. (2002). Biti digitalan [Being digital]. Zagreb: Sysprint

32. Scott, J.; Marshall, G. (2009). Oxford Dictionary of Sociology (third revised edition). Oxford (UK): Oxford University Press

33. Paić, Ž. (2007). Dekonstrukcija slike - od mimezisa, reprezentacije do komunikacije [Image deconstruction - from mimesis, representation to communication]. Centar za vizualne studije, 26 October 2007. http://www.vizualnistudiji.com/skupovi/vkk_paic.html (accessed: 1 July 2017) 
34. Pelivan, A. (2017). Više nismo guske u magli kad su u pitanju društvene mreže [When it comes to social networks we are no longer geese in the fog]. Media Marketing, February 2017. http://www.mediamarketing.com/tema-sedmice/vise-nismo-guske-umagli-kad-su-u-pitanju-drustvene-mreze/ (accessed: 12 July 2017)

35. Plavljanić, B. (2012). Povijest društvenih mreža [The history of social networks]. PC Chip (196), 27 June 2012, p. 17

36. Prensky, M. (2001). Digital Natives, Digital Immigrants (Part 1), pp. 1-6, in: On The Horizon, Vol. 9, No. 5. Bingley (UK): MCB University Press

37. Reić, A. (2015). Nova generacija mladih - generacija $\mathrm{Z}$ [New generation of youth - generation Z]. Europa.eu, $12 \quad$ November 2015. https://europa.eu/youth/hr/article/39/31499_fi (accessed: 10 July 2017)

38. Riva, G. (2004). Psicologia dei nuovi media [Psychology of new media]. Bologna: Il Mulino

39. Rodin, Z. (2016). Što je hashtag \# i čemu služi [What is a hashtag \# and what i sit used for]. BizIT.hr, 12 January 2016. https://www.bizit.hr/sto-je-hashtag-icemu-sluzi/ (accessed: 11 July 2017)

40. Rouse, M. (2014). Facebook: Definition. WhatIs.com, August 2014. http://whatis.techtarget.com/definition/Facebook (accessed: 12 July 2017)

41. Socialmarketing.org (2017). Generations X, Y, Z and the Others. WYSchroer, February 2017. http://socialmarketing.org/archives/generations-xyz-and-the-others/ (accessed: 13 July 2017)

42. Šišak, M. (2009). Javnost i novi mediji [The public and new media], pp. 77-94, in: Labaš, Danijel (ed.). Novi mediji - nove tehnologije - novi moral [New media - new technologies - now morality] (proceedings from Round table with international participation). Zagreb: Hrvatski studiji Sveučilišta u Zagrebu

43. Tancer, B. (2010). Klik - što milijuni ljudi rade na internetu $i$ što to govori o njima [Click - what millions of people do on the Internet and what it says about them]. Zagreb: Algoritam
44. Teen385 (2014). Tinejdžeri napuštaju Facebook - znate li na koje mreže odlaze? [Teenagers abandoning Facebook - do you know which networks they are leaving for?]. 22 August 2014. http://www.teen385.com/techno/noviteti/tinejdzerinapustaju-facebook-znate-li-na-koje-mreze-odlaze (accessed: 3 July 2017)

45. Tjurou, Dž. (Turow, Joseph) (2012). Mediji danas: Uvod u masovne komunikacije [Media today: Introducton into mass communication]. Belgrade: Clio

46. Tportal (2016). Gotovo svaki drugi stanovnik Hrvatske koristi društvene mreže [Almost every other inhabitant in Croatia uses social networks]. 1 February 2016. https://www.tportal.hr/tehno/clanak/gotovosvaki-drugi-stanovnik-hrvatske-koristi-drustvenemreze-20160201 (accessed: 9 July 2017)

47. Uzelac, A. (2008). Informacijsko društvo - tržište ili civilno društvo? [Information society - market or civil society], pp. 75-104, in: Peruško, Z. (ed.). Mediji, kultura $i$ civilno društvo [Media, culture and civil society]. Zagreb: Naklada Jesenski i Turk and Hrvatsko sociološko društvo

48. Van Dijk, J. (2012). The Network Society (third edition). New York (USA): SAGE Publications Ltd

49. Vitas, Z. (2016). U Hrvatskoj je više od 1,9 milijuna ljudi aktivno na Facebooku [Over 1.9 million people in Croatia are active on Facebook], Večernji list, 1 December 2016. https://www.vecernji.hr/techsci/uhrvatskoj-je-vise-od-19-milijuna-ljudi-aktivno-nafacebooku-1132516 (accessed: 6 July 2017)

50. Zgrabljić Rotar, N. (2011). Masovni mediji i digitalna kultura [Mass media and digital culture], pp. 2551, in: Zgrabljić Rotar, Nada (ed.). Digitalno doba: masovni mediji $i$ digitalna kultura [Digital age: mass media and digital culture]. Zadar: Sveučilište $\mathrm{u}$ Zadru and Naklada Medijska istraživanja

51. Žugaj, M.; Dumičić, K.; Dušak, V. (2006). Temelji znanstvenoistraživačkog rada: Metodologija i metodika [The foundations of scientific research: Methodology and methodics] (second amended and revised edition). Varaždin: Fakultet organizacije i informatike 


\title{
BIJEG S "VIRTUALNOG KORZA" - NOVI TRENDOVI PRIPADNIKA GEN- ERACIJE „ZZ U KORIŠTENJU DRUŠTVENIH MREŽA
}

\author{
Tomislav Levak, Snježana Barić Šelmić \\ Odjel za kulturologiju, Sveučilište Josipa Jurja Strossmayera u Osijeku, Osijek, Hrvatska
}

\section{Sažetak}

Cilj ovoga rada jest utvrditi prati li i mlađa populacija u Hrvatskoj vladajuće svjetske trendove u pogledu korištenja društvenih mreža kao iznimno raširenih komunikacijskih platformi. Naime, premda Facebook zajednica trenutno okuplja čak oko dvije milijarde korisnika i još uvijek je uvjerljivo globalno najpopularnija društvena mreža, u svjetskim razmjerima već je zabilježena pojava da pripadnici tzv. Generacije "Z" (osobe rođene nakon 1995. godine) sve više napuštaju ili minoriziraju Facebook i okreću se drugim društvenim mrežama.

U tu svrhu, uz iznošenje nužnog teorijskog okvira, autori su uporabom komparativne metode napravili usporedbu pojedinih suvremenih društvenih mreža te aktualnih kretanja u svijetu i Hrvatskoj u pogledu njihova korištenja. Također, tijekom mjeseca svibnja 2017. godine provedeno je istraživanje internetskih navika i stavova o društvenim mrežama - kakvo, po saznanjima autora rada, još nije provedeno u Hrvatskoj putem metode online ankete među učenicima srednjih škola, članova Generacije „Z", u nekoliko većih i manjih hrvatskih gradova: Zagrebu, Osijeku, Krku i Korčuli.

Rezultati istraživanja potvrdili su početne postavke autora rada: mladi sve više napuštaju Facebook kao „virtualni korzo“, dobrim dijelom i jer su ga učestalo počele koristiti starije generacije, među kojima i njihovi roditelji; a većinom se okreću društvenim mrežama koje im nude prevlast slike nad tekstom, u prvom redu Instagramu i Snapchatu. Osim toga, utvrđeno je kako ne postoje osjetne razlike između preferencija članova Generacije "Z" u većim urbanim sredinama na kontinentu te u manjim urbanim sredinama na jadranskim otocima.

\section{Ključne riječi}

društvene mreže, „,Z“ generacija, komunikacijske platforme, Facebook, Instagram, Snapchat 